\title{
KEBIJAKAN PEMERINTAH SURABAYA DALAM MENANGANI BERITA HOAX (Studi kasus di kota Surabaya)
}

\author{
Pitri Megasari \\ Universitas Muhammadiyah Yogyakarta \\ Rukeman no 36 rt 03 gatak tamantirto \\ Email: Megasarifitri1@gmail.com
}

\begin{abstract}
This paper discusses how government policies in counteracting hoax news in the community through social media. Some time lately more rampant news about the spread of fake news or hoaxes through online social media such as Twitter, Facebook, Instagram and YouTube. The formulation of the problem here is how the Surabaya government policy to overcome or handle the existence of false news or hoaxes in the Surabaya community. The research method for this type of research is qualitative. The data used are qualitative data, expressed in words or sentences. This false information or hoax was made deliberately because it was to influence the public because of the increasingly widespread stimulant factors such as social and political issues. Social media is now widely used to negative things like one of the accounts that spread hoax information just to increase the popularity of the account or want to be viral by spreading hoax news. Social media makes it easier for us to interact with many people and easier to convey information. But this social media makes a lot of people addicted and many social groups appear that deviate from the norms that exist in the Surabaya city government trying continuously to deal with fake news or hoaxes that are widely spread among the citizens of Surabaya.
\end{abstract}

Keywords: Government Policy, Hoax News, Society

\begin{abstract}
Abstrak: Paper ini membicarakan tentang bagaimana kebijakan pemerintah dalam menangkal berita hoax yang ada di masyarakatmelalui media sosial. Beberapa waktu belakangan ini lagi maraknya berita tentang penyebaran berita palsu atau hoax melalui media sosial online seperti twitter, facebook, instagram dan youtube. Rumusan masalah disini yaitu bagaimana kebijakan pemerintah surabaya mengatasi atau menangani adanya berita palsu atau hoax di masyarakat Surabaya. Metode penelitiannya untuk Jenis Penelitiannya yaitu kualitatif. Data yang digunakan yaitu data kualitatif, dinyatakan dalam bentuk kata atau kalimat. Informasi palsu atau hoax ini memang dibuat sengaja karena untuk mempengaruhi publik lantaran karena semakin maraknya factor stimulant seperti isu sosial dan politik. Media sosial sekarang banyak digunakan ke hal-hal yang negative seperti salah satu akun yang menyebarkan informasi hoax hanya untuk menaikan popularitas dari akun tersebut atau ingin menjadi viral dengan cara menyebarkan berita hoax. Media sosial mempermudah kita untuk berinteraksi dengan banyak orang dan lebih mudah untuk menyampaikan informasi. Tetapi media sosial ini banyak membuat orang orang kecanduan dan banyak muncul kelompok-kelompok sosial yang menyimpang dari norma-norma yang ada di pemkot Surabaya berupaya terus menerus untuk menangani berita palsu atau hoax yang banyak tersebar di kalangan warga Surabaya.
\end{abstract}

Kata kunci: Kebijakan Pemerintah, Berita Hoax, Masyarakat 


\section{Pendahuluan}

Paper ini akan membicarakan atau membahas tentang media sosial yang ada di Indonesia dan bagaimana kebijakan pemerintah dalam mengatasi berita palsu atau hoax yang tersebar luas di media sosial.

Paper ini membicarakan tentang bagaimana kebijakan pemerintah dalam menangkal berita hoax yang ada di masyarakatmelalui media sosial. Beberapa waktu belakangan ini lagi maraknya berita tentang penyebaran berita palsu atau hoax melalui media sosial online seperti twitter, facebook, instagram dan youtube. Dalam penyebaran berita palsu atau hoax ini sangat berakibat fatal karena berita ini tidak hanya membodohi masyarakat dengan informasi-informasi yang tidak benar tetapi berita hoax tersebut juga dipakai oleh pihak-pihak yang tidak bertanggung jawab untuk memecah belah masyarakat dan akan membahayakan persatuan bangsa Indonesia ${ }^{1}$.

Pemerintah mengeluarkan bentuk ketegasannya karena semakin maraknya pensebaran berita yang tidak benar. Untuk pihak-pihak yang menyebarkan berita palsu atau hoax dari kepolisian ini sendiri

1 Siswoko, K. H. Kebijakan Pemerintah Menangkal Penyebaran Berita Palsu atau 'Hoax'. (Jurnal Muara Ilmu Sosial: Humaniora, dan Seni, 2017), h. 1. sudah mengeluarkan ancaman hukum untuk diproses ("Unreliable online news", 2017). Tetapi adanya kebijakan ini membuat beberapa anggapan orang-orang menjadi salah satu kritik ancaman terhadap kebebsan berpendapat. Rudiantara seorang Menteri Komunikasi dan Informasi mengatakan berita palsu yang beredar di media sosial sepanjang hari akan membawakan dampak yang sangat besar. Memblokir situs internet merupakan salah satu cara yang dilakukan oleh pemerintah untuk mengurangi pensebaran berita palsu (Siswoko, 2017).

Media sosial ini memiliki pandangan yang berbeda-beda bagi setiap orang yang membacanya, terkadang saat kita salah dalam menulis pesan lewat media sosial akan berakibat timbulnya perbedaan pendapat atau persepsi setiap orang itu beda-beda pendapat ${ }^{2}$. Dengan adanya berita palsu atau hoax ini juga membuat perubahan sosial kepada masyarakat seperti dampak positif dan negatif, untuk dampak positifnya sendiri telah membawa pengaruh yang lebih baik sedangkan untuk dampak negatifnya sendiri lebih cenderung membawa pengaruh perubahan sosial masyarakat

${ }^{2}$ Lubis, M. S. I. Dampak Komunikasi Dan Perubahan Sosial Bagi Pengguna Instagram (Studi Deskriptif Kualitatif bagi pengguna Media Sosial Instagram di Instansi Dinas Pendidikan Sumatera Utara). (Warta Dharmawangsa, 2018), h. 55. 
yang menghilangkan nilai-nilai ataupun norma di masyarakat Indonesia (Cahyono, 2016).

Mahasiswa maupun masyarakat
yang akan menjadi generasi seterusnya
yang sangat aktif untuk mengakses
berbagai informasi dengan melalui suatu
media sosial. Macam-macam jenis
informasi yang dapat diperoleh secara
cepat dan tepat dan secara bersamaan
diperolehnya misalkan seperti tentang informasi, masalah politik atau sosial yang akan bertindak merusak adanya pemilihan umum. Untuk mengakses informasi ini sangat bahaya bagi seorang pelajar atau mahasiswa maupun masyarakat agar menggunakan berita yang tidak benar masyarakat maupun mahasiswa sangat mudah untuk termakan dengan berita yang tidak benar kejadiannya dan belum pasti kebenarannya. Dengan era informasi mahasiswa maupun masyarakat saat ini membutuhkan kemampuan seperti literasi digital yang didalamnya itu literasi ini merupakan sebuah hasil dari perkembangan adanya suatu perkembangan digital, menurut Gilster 1997 mengatakan dengan adanya literasi ini tidak hanya harus mempunyai kemampuan untuk membaca saja ini juga harus bisa mempunyai kemampua memahami dan diharuskan juga bisa mendapatkan informasi dari sumber digital yang sudah ada. Informasi akademik maupun non akademik sangat dibutuhkan oleh pemikir kritis dan ditemukan pada suatu media digital.

\section{Rumusan Masalah}

1. Bagaimana kebijakan pemerintah surabaya mengatasi atau menangani adanya berita palsu atau hoax di masyarakat Surabaya

2. Mengetahui kebijakan pemerintah surabaya mengatasi atau menangani adanya berita palsu atau hoax di masyarakat Surabaya

\section{Metode Penelitian}

1. Jenis Penelitian

Jenis penelitiannya yang akan diteliti adalah jenis kualitatif. Kualitatif itu sendiri merupakan suatu data yang didalamnya bukan bentuk angka tetapi dalam bentuk kata-kata yang verbal, penelitian kualitatif ini seperti gambaran umum obyek penelitiannya itu gimana, misalkan seperti sejarah singkat berdirinya penelitian tersebut atau bagaimana letak geografis obyek tersebut.

2. Data

Data yang digunakan yaitu data kualitatif, dinyatakan dalam bentuk kata atau kalimat. Data juga 
diambil dari perundang-undangan, internet, jurnal maupun buku-buku.

\section{Literature Review}

Informasi palsu atau hoax ini memang sangat disengaja dibuat agar bisa mempengaruhi dunia publik dikarenakan lantaran semakin marak adanya factorfaktor stimulant seperti isu-isu sosial dan politik. Media sosial sekarang banyak digunakan ke hal-hal yang negative seperti salah satu akun yang menyebarkan informasi hoax hanya untuk menaikan popularitas dari akun tersebut atau ingin menjadi viral dengan cara menyebarkan berita hoax.

Media sosial mempermudah kita untuk berinteraksi dengan banyak orang dan lebih mudah untuk menyampaikan informasi. Tetapi media sosial ini banyak membuat orang orang kecanduan dan banyak muncul kelompok-kelompok sosial yang menyimpang dari norma-norma yang $\mathrm{ada}^{3}$.

Perubahan-perubahan yang dialami oleh komunikasi konvensional ini menjadi lebih modern dan juga menjadi serba digital dan bisa menjadikannya lebih pesatnya perkembangan teknologi ${ }^{4}$

\footnotetext{
${ }^{3}$ Cahyono, A. S. Pengaruh media sosial terhadap perubahan sosial masyarakat di Indonesia. (Jurnal Publiciana 9(1), 2016), h. 140-157.

${ }^{4}$ Solekhan, S. \& Winarso, R. Pemanfaatan Media Sosial Sebagai Media Pemasaran Sangkar Burung di Kabupaten Kudus. (Prosiding SNATIF, 2016), h. 445-448.
}

(Effendy 2006), Perkembangan yang dilakukanpun dapat menjadikannya semakin pesat setelah internet mulai dapat diakses melalui telephone genggam maupun telephone seluler. Dengan pemanfaatan media sosial untuk pemasaran sangkar burung proses produksinya menjadi lebih efektif dan efisien. Dengan adanya pemasaran baik lokal, nasional maupun global sehingga pendapatan pengrajin pada khususnya bisa meningkat serta peningkatan pendapatan daerah pada umumnya maka adanya juga perluasan daerah.

Dengan adanya komunikasi bagi pemerintah yang dijalankan oleh Ridwan Kamil dan juga berserta jajaran dari Pemkot lebih dipermudahkan alur birokrasi pemerintahnya yang selama ini biasanya lambat dan sekarang bisa menjadi lebih baik lagi. Ada dua kemungkinan mengapa Ridwan Kamil menggunakan media sosial seperti instagram, twitter dan facebook untuk aktivitas komunikasi sehari-harinya dengan pemerintahannya yaitu yang pertama Ridwan Kamil memiliki mimpi untuk bisa berbagi kemanfaatan yang dia miliki seperti media sosial dan kreatifitas dan kekuasaan dia sebagai wali kota bandung untuk berbagi kepada masyarakat bandung 5 . Alasan yang

\footnotetext{
${ }^{5}$ Munandar, H. \& Suherman, M. Aktivitas Komunikasi Pemerintahan Ridwan Kamil di Media
} 
kedua yaitu lebih menonjol kesifat pribadinya karena ini merupakan hasil refleksi dari kepercayaan spiritual yang pernah dipercaya. (Purworini, D, 2017) menurutnya Humas pemda Sukoharjo menggunakan model komunikasi satu arah dan menjelaskan nilai utama yang melekat dalam komunikasi di humas pemda.

Fenomena hoax yang akhir-akhir ini sedang marak terjadi di Indoensia adalah menimbulkan keresahan di kalangan masyarakat dapat disikapi melalui perilaku dari masyarakat itu sendiri yaitu masyarakat dapat diharapkan lebih cerdas dalam menggunakan teknologi yaitu bisa lebih bijak dalam menyikapi informasi yang sudah beredar. Ketika menerima informasi media sosail yang harus ia lakukan terlebih dahulu adalah lebih dulu mengecek literasi kebenaran berita jika informasi dan berita yang diterima hanyalah sebuah hoax atau palsu sebaiknya masayarakat tidak menyebarkan atau membagikan informasi tersebut. Perkembangan teknologi yang semakin berkembang seperti media sosial juga mempengaruhi perilaku sosial masyarakat Indonesia.Kehadiran media

\footnotetext{
Sosial. (Jurnal Hubungan Masyarakat, Gelombang, 1, 2015-2016, 2016)
}

sosial dapat memberikan hal yang positif dan negative bagi masyarakat ${ }^{6}$.

Hadirnya berbagai macam media sosial memberikan dampak yang sangat besar bagi masyarakat dan juga kehidupan. Para pengguna internet di seluruh Indonesia ini lebih mengistimewakan media sosial sebagai alat komunikasinya. Hingga dari delapan puluh lebih persen orang yang menggunakan internet diseluruh Indonesia saat ini berbagai warga agar bisa mengakses ke jejaring media sosial. Pemerintah Indonesia secara perlahan sudah menggunakan medsos ini sebagai alat komunikasi kepada warga setempat karena ini lebih mudah dan cepat untuk mendapatkan informasi yang dapatkan. Yang menjadi perhatian pada saat ini yaitu pengguna media sosial di seluruh Indonesia sangat besar dan tetapi partisipasi dari masyarakatnya terhadap akun media sosial milik pemerintah ini masih sangatlah rendah ${ }^{7}$.

$$
\text { Menurut }
$$

kawan-kawan

Penggunaan e-government seperti media sosial oleh pemerintah daerah sebenarnya hanya untuk digunakan adanya interaksi antara masyarakat dengan pemerintah.

${ }^{6}$ Pakpahan, R. Analisis Fenomena Hoax Diberbagai Media Sosial dan Cara Menanggulangi Hoax. (Konferensi Nasional Ilmu Sosial dan Teknologi, 2017), h. 1.

7 Suryadharma, B. \& Susanto, T. D. Faktor Penerimaan Media Sosial Instansi Pemerintah di Indonesia. (INTEGER: Journal of Information Technology, 2017), h. 2. 
Tetapi e-government ini belum mendapatkan respon dari masyarakatnya itu sendiri. Unggahan atau posting yang berupa gambar dan juga video dalam situs web media sosial akan mendapatkan respons yang sangat positif dibandingkan dengan unggahan atau postingan teks. Terjadi hal tersebut karena adanya unsur audio dan juga unsur visual yang lebih kreatif dan juga interaktif. Masyarakat lebih cenderung untuk memilih dan juga menerima informasi-informasi melalui postingan video dibandingkan postingan gambar ataupun teks ${ }^{8}$.

Pengunggahan pesan didalam sebuah akun instagram Humas Pemerintah Kota Surabaya sebenarnya hanya untuk media publikasi saja yang berisi tentang kota surabaya seperti lingkungannya, kegiatan yang diadakan oleh Pemerintah Kota Surabaya ${ }^{9}$. Susanto, E. H. (2017) berpendapat juga dengan berkembangannya jaringan teknologi komunikasi dan informasi maka semakin memudah juga kita untuk berinteraksi antar individu maupun kelompok.

${ }^{8}$ Furqon, M.A. Hermansyah, D. Sari, R. Sukma, A. Akbar, Y. \& Rakhmawati, N.A. Analisis Jenis Posting Media Sosial Pemerintah Daerah di Indonesia Berdasarkan Like dan Analisis Sentimental Masyarakat. (Jurnal Sosioteknologi, 17(2), 2018), h. 177-190.

9 Sofiana, M. Instagram Sebagai Media Publikasi Humas Pemerintah Kota Surabaya. (UIN Sunan Ampel Surabaya: Doctoral dissertation, 2016)
Pemerintah disini memilih media sosial untuk menjembatani komunikasi karena kondisi masyarakat Indonesia saat ini sudah tidak asing lagi dengan namanya media sosial $^{10}$. Media sosial sekarang semakin popular dan ini dapat menjadi potensi pariwisata di Indonesia untuk membangun promosi melalui facebook, twitter, instagram dan blog pribadi ${ }^{11}$. Keberadaan dari situs media sosial ini mampu membuat suatu perilaku seorang responden menjadi pengguna atau pengikut yang aktif dan dapat juga berbagi sesama informasi yang didapatkan ${ }^{12}$.

Media sosial merupakan media untuk berinteraksi dan juga untuk salah satu sebagai media komunikasi antar pemerintah dan juga masyarakat ${ }^{13}$. Media sosial memiliki dampak yang negatif terhadap pendidikan akhlak anak yaitu

10 Abadi, A.N. Rancang Bangun Perangkat Lunak Benchmarking Sosial Media Pemerintah Daerah Indonesia (Institut Teknologi Sepuluh Nopember: Doctoral dissertation, 2017).

11 Hamzah, Y.I. Potensi media sosial sebagai sarana promosi interaktif bagi pariwisata Indonesia. (Jurnal Kepariwisataan Indonesia, 8(3), 2013), h. 1-9.

12 Nurrohman, M. F. \& Nofrandilla, N. Pemerintah dan Media Sosial Studi Deskriptif Kuantitatif Persepsi Pegawai Humas dan Protokol SETDA Surakarta Terhadap Media Sosial. (Universitas Muhammadiyah Surakarta: Doctoral dissertation, 2016).

${ }^{13}$ Izzati, A. N. Pratama, A. Aristamy, I. G. A. A. M. Najwa, N. F. \& Rakhmawati, N. A. Kategorisasi Jenis Interaksi antara Pemerintah dan Masyarakat dan Popularitas Media Sosial Pemerintah Daerah. (Jurnal Sistem Informasi, 14(1), 2018), h. 1-8. 
Pitri Megasari

Kebijakan Pemerintah Surabaya Dalam Menangani Berita Hoax(Studi Kasus Di Kota Surabaya)

anak-anak lebih dipermudahkan untuk menyelesaikan tugasnya. Dan dampak negatifnya anak-anak menjadi lebih malas, dan bisa lalai dalam mengerjakan tugas ${ }^{14}$.

Presiden Jokowi sudah mempunyai citra pemimpin dari masih ia kecil. Bulan desember tahun 2016 sampai Januari tahun 2017 banyak mucul kabar di situs medsos dan berbeda pada gambar. Tujuan dari penelitian ini untuk menemukan framing pemberitaan pemerintah tidak mendominasi informasi di media sosial. Dominannya berita biasanya merupakan suatu fakta yang sebagian beritanya dihilangkan untuk memyembunyikan suatu fakta tersebu ${ }^{15}$ Dalam D., \& Suryawardani, B. (2017) Industri kreatif dipercaya oleh pemerintah untuk sebagai suatu harapan dan juga untuk ekonomi Indonesia supaya bisa bangkit lagi, bersaing dan bisa meraih keunggulan dalam ekonomi global. Tujuan dari Niion ini bagaimana cara melakukan promosi di salah satu media sosial yaitu instagram dan juga untuk mengetahui bagaimana tanggapan oleh seorang responden mengenai media sosial Instagram Niion

${ }^{14}$ Khairuni, N. Dampak positif dan negatif sosial media terhadap pendidikan akhlak anak (studi kasus di smp negeri 2 kelas viii banda aceh). (Jurnal Edukasi: Jurnal Bimbingan Konseling, 2(1), 2016), h. 91-106.

15 Jaya, P.H.I. Distorsi Komunikasi Pembangunan Pemerintahan Presiden Jokowi di Media Sosial. (2017) dan juga serta untuk mengetahui efektivitas media sosial Instagram Niion untuk menarik minat pembelian konsumen.

Hadirnya volunterisme pada pemilihan umum pada tahun 2014 dari kelas menengah Indonesia membuat adanya tampilan baru. Penggunaan dari medsos ini lebih penting untuk mendorong kesadaran politik kelas menengah dan menjadikannya lebih efektif. Pengaruh media sosial untuk kalangan kelas menengah sudah bisa membentuk preferensi politik secara kekinian. Sifat yang lebih terhubung ini bisa mengindikasi bahwasannya kelas ini merupakan kelas yang ingin terus menerus mengetahui adanya informasi dari jejaring medsos ${ }^{16}$.

Untuk mengubah karakteristik supaya menjadi karakteristik yang semula misalkan apolitis menjadi politis maka perlu adanya dorongan dari media sosial.

Saat ini dengan adanya media sosial kebebasan berpendapat semakin terbuka. Dari media sosial twitter kasus KPK bersama polisi banyak mendapat tanggapan. Opini yang terbentuk beberapa hari ini adalah KPK disini posisinya masih benar sedangkan polisi masih didalam posisi yang sangat salah. Tujuannya untuk

16 Jati, W. R. Aktivisme kelas menengah berbasis media sosial: Munculnya relawan dalam pemilu 2014. (Jurnal Ilmu Sosial dan Ilmu Politik, 20(2), 2016), h. 147-162. 
mendapatkan bagaimana gambaran opini terbentuk ${ }^{17}$.

Medsos seperti instagram ini merupakan media sosial yang efektif untuk menyebarkan berita dan juga bisa mendidik masyarakat tentang bagaimana migrasi dan juga teknologi TV digital. Penelitian yang pertama ini menjelaskan tentang tidak terdapat adanya perbedaan antara pengetahuan yang signifikan yang sebelum dan sesudah ada pemberian tretment pesan tentang TV digital melalui media sosial instagram di kalangan mahasiswa ataupun mahasiswi, dan penelitian kedua menjelaskan tentang informasi seputar migrasi TV Digital karena kurang menariknya bagi kalangan mahasiswa bagi pengguna instagram. Instagram belum cukup efektif sebagai media sosialisasi dikarenakan belum cukupnya materi ${ }^{18}$.

\section{Kerangka Teori}

\section{Kebijakan Pemerintah}

Kebijakan ini merupakan suatu keputusan yang sengaja dibuat secara sistematik oleh pemerintah, kebijakan pemerintah ini memiliki tujuan tertentu yang menyangkut masalah kepentingan

\footnotetext{
${ }^{17}$ Juditha, C. Opini Publik terhadap Kasus "KPK Lawan Polisi" dalam Media Sosial Twitter. (Pekommas, 17 (2), 2014)

${ }^{18}$ Prabowo, A. \& Arofah, K. Media Sosial Instagram sebagai Sarana Sosialisasi Kebijakan Penyiaran Digital. (Jurnal ASPIKOM, 3(2), 2017), h. 256-269.
}

bagi umum. Tujuan dari kebijakan pemerintah itu sendiri yaitu untuk menciptakan suatu ketertiban, kedamaian, ketenteraman dan juga untuk mewujudkan suatu kesejahteraan di lingkungan masyarakat setempat. Sifat-sifat dari kebijakan pemerintah itu sendiri yaitu lebih bersifat ke distributif itu sendiri yaitu (pada kebijakan yang satu ini yang bersifat distributif dalam membagikan ataupun mengalokasikan suatu sumber-sumber material yang telah didapatkan kemudian dibagikan kepada masyarakat luas), ekstraktif yaitu (kebijakan yang satu ini yaitu artinya suatu penyerapan terhadap sumber-sumber material dari masyarakat yang luas) dan yang terakhir regulative (kebijakan satu ini merupakan suatu kebijakan yang berisikan suatu peraturan dan juga kewajiban yang harus dipatuhi oleh warga masyarakat/negara dan juga diselenggarakan penyelenggara untuk menciptakan sebuah ketertiban dan juga kelancarannya).

2. Berita

Berita ini merupakan suatu tindakan laporan tentang peristiwa yang terkini dan juga penting disampaikan kepada masyarakat dengan secara cepat dan tepat. Dalam penyampaian atau penyajian sebuah berita dapat 
menggunakan media seperti surat kabar, televisi, radio dan media online. Berita ini juga memiliki arti yang berbeda yaitu sebuah berita yang faktanya tentang berlangsungnya suatu kejadian. Selain itu berita juga dapat dikatakan sebagai sebuah laporan keterangan dari sebuah peristiwa. Berita merupakan sebuah fakta yang harus segera disampaikan kepada masyarakat.

Adapun jenis-jenis berita yaitu yang pertama adalah Straight News jenis berita secara langsung yang beritanya berisikan dituliskan secara singkat dan apa adanya. Berita yang berjenis Straight News dapat ditemui pada halaman pertama surat kabar. Jenis berita Straight News terbagi menjadi 2 yaitu Hard News dan Soft News. Sedangkan jenis berita yang kedua yaitu Depth news yaitu informasi yang memiliki isi bersifat lebih lengkap dan jelas. Dept News biasanya terdapat ulasan-ulasan yang mendalam terhadap suatu peristiwa. Berita sejenis ini isinya itu lebih mengarah tentang mengapa dan bagaimana peristiwa tersebut bisa terjadi. Tujuan dari berita Depth News jenis ini untuk mengangkat suatu kejadian yang pernah terjadi secara lebih mendalam. Jenis yang ketiga yaitu Investigation News merupakan cara pembuatannya terhadap penelitian yang dilakukan dari bemacam sumber yang ada. Dalam menulis Investigation News biasanya jurnalis mempunyai tujuan tertentu seperti untuk membongkar tindak kriminal yang sangat merugikan dan meresahkan masyarakat dan membongkar sebuah jaringan penjualan illegal. Jenis yang keempat yaitu Interpretative merupakan suatu berita yang pengembangannya dari jenis straight news. Interpretative new merupakan dimana didalamnya itu ditambahkan beberapa informasi dan juga merupakan berita secara langsung misalkan seperti pendapat seseorang yang dituliskan kembali oleh penulis. Untuk jenis yang terakhir ini yaitu Opinion News pengertiannya yaitu suatu berita yang berisikan suatu opini yang sedang terjadi. Biasanya isi dari jenis berita ini adalah pendapat dari para pengamat atau para ahli dari masalah, isu atau dari kejadian yang sedang terjadi. Selain itu pendapat juga dapat diperoleh dari masyarakat, pelajar ataupun mahasiswa.

\section{Hoax}

Menurut pendapat Werme (2016) mendefiniskan pengertian hoax sebagai suatu berita palsu yang mengandung berbagai informasi yang memang sengaja untuk menyesatkan orang-orang dan juga memiliki agenda politik. Ada 
dua versi yang terkait dengan adanya sejarah hoak yaitu pertama yang dicatat pada tahun 1661 dan memiliki suatu kasus yaitu soal drummer of tedworth yang bercerita tentang John Mompesson yaitu seseorang yang dihantui adanya suara drum disetiap malamnya. Ia mendapatkan nasib tersebut dikarenakan ia pernah menuntut menuntut William Drury yaitu salah satu drummer band gipsy dan akhirnya ia berhasil menang. Pada saat ini juga hoax merupakan berita palsu yang juga sering muncul di situs internet dan memiliki tujuan untuk menyebabkan ketakutan kepada masyarakat dan kegiatan yang dilakukan dari oknum yang menyebarkan berita palsu tersebut tidak bertanggung jawab atas apa yang sudah diperbuat. Via email merupakan penyebaran berita hoax internet pertama yang diketahui yang berisi peringatan akan hal sebuah berita hoax. Semakin berkembangnya smartphone dan media sosial maka semakin banyak juga berita hoax didalam internet dan juga akan menimbulkan perpecahan sesama masyarakat.

Berita palsu atau hoax ini bisa menyebabkan kerusuhan yaitu dimana diatur dalam dua ketentuan UndangUndang Nomor 1 Tahun 1946 tentang Hukum Pidana. Pasal 14 Undang-
Undang menegaskan: ayat 1 "barangsiapa, dan dengan menyiarkan berita palsu dengan secara sengaja menyebabkan keonaran dikalangan rakyat atau masyarakat akan dihukum dengan penjara yang setinggi-tingginya yaitu sepuluh tahuh dalam ayat 2 "barangsiapa mengeluarkan pemberitahuan yang dapat menyebabkan keonaran dikalangan rakyat sedangkan dia patut dapat menyangka bahwa berita tersebut adalah berita palsu maka akan dihukum dengan penjara setinggi-tingginya tiga tahun. Pembeda dari dua ketentuan diatas yaitu pada ayat kesatu merupakan perbuatan menyebarkan berita palsu akan tetapi menyebabkan keonaran karena kesengajaan sebagai maksud atau kepastian.

Beberapa penjabaran secara singkat terkait pasal-pasal dalam Undang-Undang yang mengatur tentang berita palsu atau hoax :

A. KUHP, 1. Pasal 311 KUHP : “jika yang melakukan kejahatan pencemaran atau pencemaran tertulis dibolehkan untuk membuktikan apa yang dituduhkan itu benar, tidak membuktikannya, dan tuduhan dilakukan bertentangan dengan apa yang diketahui, maka dia diancam melakukan fitnah dengan pidana 
penjara paling lama empat tahun."

2. Pasal 378 kuhp : "barang siapa dengan maksud untuk menguntungkan diri sendiri atau orang lain secara melawan hukum, dengan memakai nama palsu atau martabat palsu, dengan tipu muslihat, ataupun rangkaian kebohongan, menggerakkan orang lain untuk menyerahkan barang sesuatu kepadanya, atau supaya memberikan hutang maupun menghapuskan piutang diancam karena penipuan dengan pidana penjara paling lama empat tahun."

B. Undang-Undang No. 1 Tahun 1946 tentang Peraturan Hukum Pidana 1. Pasal 14 ayat (1) dan (2): Ayat 1 "barangsiapa dengan mudah menyiarkan berita palsu dengan secara sengaja menyebabkan keonaran dikalangan masyarakat maka akan dihukum dengan hukuman penjara setinggitingginya sepuluh tahun." Ayat 2 "barangsiapa menyiarkan suatu berita atau mengeluarkan suatu pemberitahuan yang dapat menerbitkan keonaran dikalangan rakyat, sedangkan ia patut dapat menyangka bahwa berita atau pemberitahuan itu adalah bohong, dihukum dengan penjara setinggitingginya adalah tiga tahun." 2 .
Pasal 15 : "barang siapa menyebarkan kabar yang tidak pasti atau kabar yang berkelebihan atau yang tidak lengkap, sedangkan ia mengerti setidak-tidaknya patut dapat menduga bahwa kabar demikian akan atau sudah dapat menerbitkan keonaran dikalangan rakyat, dihukum dengan hukuman penjara setinggi-tingginya dua tahun.

C. Undang-Undang No.19 Tahun 2016 tentang suatu Informasi dan Transaksi Elektronik. 1. Pasal 27 ayat (3): "setiap orang dengan sengaja, dan tanpa hak mendistribusikan dan/atau mentransmisikan dan/atau membuat dapat diaksesnya Informasi Elektronik dan/atau Dokumen Elektronik yang memiliki muatan penghinaan dan/atau pencemaran nama baik." 2. Pasal 28 ayat (1) dan (2): Ayat 1 "setiap orang yang dengan sengaja dan tanpa hak menyebarkan berita bohong dan menyesatkan yang mengakibatkan kerugian konsumen dalam transaksi elektornik." Ayat 2 "setiap orang dengan sengaja dan tanpa hak menyebarkan informasi yang ditujukan untuk menimbulkan rasa kebencian atau pemusuhan individu dan/atau kelompok 
masyarakat tertentu berdasarkan atas suku, agama, ras, dan antar golongan (SARA).

\section{Hasil Dan Pembahasan}

Pemkot surabaya terus menerus menangani adanya berita palsu atau hoax yang banyak tersebar dikalangan masyarakat setempat. Berbagai macam upaya pemerintah kota surabaya untuk menangani berita palsu atau hoax ini di Indonesia. Supaya informasi-informasi yang tidak pasti kebenarannya itu akan terus membuat masyarakat menjadi resah dan membuat sesama masyarakat bisa bertengkar bagi masyarakat kota surabaya. Hendry Simanjuntak selaku kepala bidang pencegahan dan kesiapsiagaan BPB linmas kota surabaya mengatakan bahwa jika ada isu atau berita yang belum pasti kebenarannya atau berita hoax yang ramai dibincangkan masyarakat baik itu melalui media sosial ataupun melalui messenger dari pihaknya langsung melakukan cek dan ricek kebenaran berita tersebut. Dari pers kantor humas pemkot Surabaya sudah ditugaskan untuk melakuakn cek dan ricek jika ada berita yang kurang mengenakan ataupun berita palsu atau hoax yang meresahkan masyarakat Indonesia khususnya warga Surabaya.
Seperti beberapa waktu yang lalu di kota Surabaya ada kabar bahwa didalam sebuah kolam renang yang airnya dapat bergerak. Dari pihak tersebut mengaku dan langsung melakukan pengecekan ke lokasi dan berkerjasama dengan pihak BMKG, kolam renang tersebut dikelola untuk memastikan benar atau tidaknya berita tersebut. Apabila kondisi tersebut sudah sangat menggangu dan meresahkan warga masyarakat surabaya. Beberapa waktu yang lalu juga ramai dengan adanya perbincangan masyarakat terkait hasil penelitian dari Institut Teknologi 10 November Surabaya (ITS) yang menyebut adanya dua patahan aktif di Surabaya. Dengan demikian dia mengaku langsung melakukan cek dan ricek untuk mengetahui kebenaran informasi tersebut.

Penelitian dari Institut Teknologi 10 November Surabaya ITS juga mengatakan jika Surabaya terjadi gempa maksimalnya hanya mencapai 6,5 skala richter itu tidak berpotensi tsunami. Syarat untuk terjadi tsunami minimal 7,5 skala richter. Pihak tersebut secara langsung akan melakukan sosialisasi mitigasi terhadap bencana ke warga masyarakat setempat. Ia juga berharap supaya masyarakat tidak perlu resah dengan adanya informasi-informasi dua patahan aktif tersebut. Tugas kami disini untuk menyampaikan kebenaran berita bukan 
kebohongan berita dan disini nantinya diharapkan masyarakat itu tidak panik duluan dan juga tidak resah terhadap berita-berita palsu atau hoax. Kepala bidang informasi dan komunikasi publik Dinas Komunikasi dan Informatika (Dinkominfo) kota Surabaya Sri Puri Suryandari menyampaikan Pemerintah kota Surabaya melalui Dinkominfo juga mempunyai peran yang sangat penting untuk menangani berita palsu atau hoax tersebut. Dari sisi pemerintahan dan juga dari sisi masyarakatnya melakukan pendekatan yaitu dengan melakukan pendekatan langsung ke masyarakat dengan bantuan organisasi KIM (Kelompok Informasi Masyarakat).

KIM disini juga sangat membantu dalam menangkal atau menangani berita palsu atau hoax tersebut. Jika ada isu atau kabar-kabar yang ramai diperbincangkan masyarakat Surabaya biasanya KIM (Kelompok Informasi Masyarakat) langsung membantu mencari kebenaran dan menyebarkan informasi tersebut. Disamping itu juga pihaknya mengaku juga mempunyai strategi khusus dalam menangkal beredarnya kabar hoax di masyarakat. Selain dibantu dengan organisasi KIM media sosial dan website resmi juga dimaksimalkan untuk menangkal beredarnya kabar hoax tersebut. Pemerintah kota Surabaya juga mempunyai media sosial Sapawarga dan juga bekerjasama dengan Bagian Humas (Bangga Surabaya). Semua ini supaya untuk masyarakat jika ada berita-berita yang tidak benar bisa disampaikan atau dibicarakan kepada pemerintah kota tersebut.

Pakar Hukum Universitas Airlangga (Unair) kota Surabaya Masitoh Indriani mengapresiasikan atas segala upaya yang telah dilakukan oleh pemerintah kota Surabaya dalam menangkal atau menangani berita-berita palsu atau hoax yang sekarang sering muncul di masyarakat. Masitoh mengungkapkan fenomena dari berita palsu atau hoax ini tidak hanya terjadi di Indonesia saja. Tetapi juga terjadi di negara-negara yang lain seperti Amerika, Filipina, Singapura dan juga Inggris. Hal tersebut dapat membuktikan bahwa ada juga masyarakat yang sudah berpendidikan tinggi pun bisa terserang atau terkena berita palsu atau hoax. Jadi dimana-mana itu orang-orang dengan tingkat pendidikan yang tinggi pun bisa terkena berita palsu atau hoax. Penelitian ini mengatakan ada tujuh media yang biasa dan biasa dijadikan alat untuk penyebaran berita palsu atau hoax. Yaitu melalui radio, email, media cetak, televisi, situs web, aplikasi chatting (whatsapp, line, telegram) dan sosial media (facebook, twitter, instagram, path). 
Tetapi kata seorang Masitoh sosial media ini masih mendominasi tertinggi sebagai alat penyebaran berita palsu atau hoax tersebut. Dengan presentase 92,40 persen dan kemudian diikuti aplikasi chatting dengan presentase 62,80 persen.

Berita palsu atau hoax ini merupakan suatu bagian yang kecil menurut bebrapa orang tetapi dampak dari berita palsu atau hoax ini sangatlah luar biasa. Apalagi jika ia menambahkan minat baca masyarakatnya menjadi salah satu indikator yang menyebabkan seseorang tersebut gampang terserang berita palsu atau hoax. Oleh karena itu menurutnya terkadang masyarakat jika mendapat suatu informasi secara langsung harus mencerna tanpa melakukan cek dan ricek bagaimana kebenaran berita tersebut apakah benar atau palsu. Menurutnya gelombang sebesar apapun itu jika literasinya kurang maka seseorang tersebut akan mudah juga terjerumus dalam berita palsu atau hoax.

Kebijakan yang diambil oleh pemerintah untuk menangani ataupun menangkal adanya berita hoax yang sudah menyebar luas di Indonesia terutama di pemerintahan kota Surabaya yaitu dengan bantuan dari pers kantor Humas pemkot Surabaya sudah di tugaskan melakuakn cek dan juga ricek jika ada berita yang kurang mengenakan ataupun berita palsu atau hoax yang meresahkan masyarakat Indonesia khususnya warga Surabaya dan juga mendapatkan bantuan dari kepala bidang informasi dan komunikasi publik dinas komunikasi dan informatika (Dinkominfo) Kota Surabaya Sri Puri Suryandari menyampaikan Pemerintah kota Surabaya melalui Dinkominfo memiliki peran yang sangat penting untuk menangkal berita palsu atau hoax.

\section{Penutup}

Jadi kesimpulannya berita palsu atau hoax ini memang sangat berakibat fatal bagi masyarakat apalagi berita ini bukan hanya membodohi masyarakat dengan informasi yang tidak benar saja tetapi juga bisa membuat masyarakat terpecah bela dan juga bisa merusak persatuan bangsa. Dan disini juga pemerintah sudah mengeluarkan bentuk dari ketegasannya yaitu ancaman hukum bagi penyebar berita palsu atau hoax. Dalam menggunakan media sosial haruslah berhati-hati dimana di dalam media sosial lah orang-orang dapat mencari kesalahan kita.Saat kita mengirim pesan lewat salah satu media sosial misalkan lewat facebook, twitter dan instagram pada saat itu juga pesan yang kita kirim ada kata-kata yang salah, itu bisa menyebabkan munculnya berita palsu ataupun hoax. Apalagi seseorang yang 
Pitri Megasari

Kebijakan Pemerintah Surabaya Dalam Menangani Berita Hoax(Studi Kasus Di Kota Surabaya)

mengirim pesan tersebut seorang figuran akan lebih cepat lagi berita palsu atau hoax tersebut tersebar. Karena seorang figuran tersebut banyak yang suka dan juga banyak yang tidak suka.

Pemkot surabaya terus menerus menangani adanya berita palsu atau hoax yang banyak tersebar dikalangan masyarakat setempat. Berbagai macam upaya pemerintah kota surabaya untuk menangani berita palsu atau hoax ini di Indonesia. Supaya informasi-informasi yang tidak pasti kebenarannya itu akan terus membuat masyarakat menjadi resah dan membuat sesama masyarakat bisa bertengkar bagi masyarakat kota surabaya. Hendry Simanjuntak selaku kepala bidang pencegahan dan kesiapsiagaan BPB linmas kota surabaya mengatakan bahwa jika ada isu atau berita yang belum pasti kebenarannya atau berita hoax yang ramai dibincangkan masyarakat baik itu melalui media sosial ataupun melalui messenger dari pihaknya langsung melakukan cek dan ricek kebenaran berita tersebut. Dari pers kantor humas pemkot Surabaya sudah ditugaskan untuk melakuakn cek dan ricek jika ada berita yang kurang mengenakan ataupun berita palsu atau hoax yang meresahkan masyarakat Indonesia khususnya warga Surabaya.

\section{Pustaka Acuan}

Siswoko, K.H. Kebijakan Pemerintah Menangkal Penyebaran Berita Palsu atau 'Hoax'. (Jurnal Muara Ilmu Sosial, Humaniora, dan Seni, 1(1), 2017)

Lubis, M.S.I. Dampak Komunikasi Dan Perubahan Sosial Bagi Pengguna Instagram (Studi Deskriptif Kualitatif bagi pengguna Media Sosial Instagram di Instansi Dinas Pendidikan Sumatera Utara). (Warta Dharmawangsa, 2018)

Rahadi, D.R. Perilaku pengguna dan informasi hoax di media sosial. (Jurnal Manajemen dan Kewirausahaan, 5(1), 2017)

Cahyono, A.S. Pengaruh media sosial terhadap perubahan sosial masyarakat di Indonesia. (Jurnal Publiciana, 9(1), 2016)

Solekhan, S. \& Winarso, R. Pemanfaatan Media Sosial Sebagai Media Pemasaran Sangkar Burung di Kabupaten Kudus. (Prosiding SNATIF, 2016)

Munandar, H. \& Suherman, M. Aktivitas Komunikasi Pemerintahan Ridwan Kamil di Media Sosial. (Jurnal Hubungan Masyarakat, Gelombang, 1, 2015-2016).

Purworini, D. Model informasi publik di era media sosial: Kajian grounded teori di pemda sukoharjo. (Komuniti: Jurnal Komunikasi dan Teknologi Informasi, 6(1), 2017)

Pakpahan, R. Analisis Fenomena Hoax Diberbagai Media Sosial dan Cara Menanggulangi Hoax. (Konferensi Nasional Ilmu Sosial dan Teknologi, 1(1), 2017)

Suryadharma, B. \& Susanto, T. D. Faktor Penerimaan Media Sosial Instansi 
Pemerintah di Indonesia. (INTEGER: Journal of Information Technology, 2(2), 2017).

Furqon, M.A. Hermansyah, D. Sari, R. Sukma, A. Akbar, Y. \& Rakhmawati, N.A. Analisis Jenis Posting Media Sosial Pemerintah Daerah di Indonesia Berdasarkan Like dan Analisis Sentimental Masyarakat. (Jurnal

Sosioteknologi, 17(2), 2018)

Sofiana, M. Instagram Sebagai Media Publikasi Humas Pemerintah Kota Surabaya(UIN Sunan Ampel Surabaya: Doctoral dissertation, 2016).

Susanto, E.H. Media sosial sebagai pendukung jaringan komunikasi politik. (Jurnal Aspikom, 3(3), 2017)

Abadi, A.N. Rancang Bangun Perangkat Lunak Benchmarking Sosial Media Pemerintah Daerah Indonesia. (Institut Teknologi Sepuluh Nopember: Doctoral dissertation, 2017).

Hamzah, Y.I. Potensi media sosial sebagai sarana promosi interaktif bagi pariwisata Indonesia. (Jurnal Kepariwisataan Indonesia, 8(3), 2013)

Nurrohman, M.F. \& Nofrandilla, N. Pemerintah dan Media Sosial Studi Deskriptif Kuantitatif Persepsi Pegawai Humas dan Protokol SETDA Surakarta Terhadap Media Sosial. (Universitas Muhammadiyah Surakarta: Doctoral dissertation, 2016).

Izzati, A.N. Pratama, A. Aristamy, I.G.A. A.M. Najwa, N.F. \& Rakhmawati, N. A. Kategorisasi Jenis Interaksi antara Pemerintah dan Masyarakat dan Popularitas Media Sosial
Pemerintah Daerah. (Jurnal Sistem Informasi, 14(1), 2018)

Khairuni, N. Dampak positif dan negatif sosial media terhadap pendidikan akhlak anak (studi kasus di smp negeri 2 kelas viii banda aceh). (Jurnal Edukasi: Jurnal Bimbingan Konseling, 2(1), 2016)

Jaya, P.H.I. Distorsi Komunikasi Pembangunan Pemerintahan Presiden Jokowi di Media Sosial. (2017).

D. \& Suryawardani, BAnalisis Efektivitas Promosi Melalui Media Sosial Instagram Pada Pt. Niion Indonesia Utama Tahun 2017. (eProceedings of Applied Science, 3(2), 2017)

Jati, W.R. Aktivisme kelas menengah berbasis media sosial: Munculnya relawan dalam pemilu 2014. (Jurnal Ilmu Sosial dan Ilmu Politik, 20(2), 2016)

Juditha, C. Opini Publik terhadap Kasus "KPK Lawan Polisi" dalam Media Sosial Twitter. (Pekommas, 17(2), 2014)

Prabowo, A. \& Arofah, K. Media Sosial Instagram sebagai Sarana Sosialisasi Kebijakan Penyiaran Digital. (Jurnal ASPIKOM, 3(2), 2017)

Izni, I. Kemampuan Literasi Digital Dalam Menilai Berita Hoax Di Media Daring Di Kalangan Mahasiswa Aktivis Universitas Airlangga Surabaya. (Universitas Airlangga: Doctoral dissertation, 2019)

Siddiq, N.A. Penegakan Hukum Pidana Dalam Penanggulangan Berita Palsu (Hoax) Menurut UndangUndang No. 11 Tahun 2008 Yang Telah Dirubah Menjadi UndangUndang No. 19 Tahun 2016 
Tentang Informasi Dan Transaksi

Elektronik. (Lex Et

Societatis, 5(10), 2017)

https://duniapendidikan.co.id/tujuan

kebijakan-pemerintah-pengertian-sifat/

https://www.menpan.go.id/site/beritaterkini/berita-daerah/beginistrategi-pemkot-surabaya-tangkalberita-hoax 